\title{
YOUNG WOMEN WRITERS FROM THE PESANTREN TRADITION Self-Initiative, Learning Environment, and the Education System ${ }^{1}$
}

\author{
Nor Ismah \\ University of Hawaii at Manoa, USA
}

\begin{abstract}
The emergence of a new generation of women writers from the pesantren tradition is an interesting issue in the landscape of Indonesian Islam. Especially, after for a long time, the authorship in the pesantren tradition has been dominated by men. This paper provides a brief description of the writing tradition in the pesantren. It examines how the writing tradition has been developed by the students. It also describes the extent to which women are involved in the writing tradition of pesantren and explores some differences between older generations and the new generation. The paper argues that the most influential factor in the writing achievement among young women writers is self-esteem and learning environments including family and pesantren. Self-esteem is partly developed in a learning environment in which the writers can sharpen their writing skills, strengthen their identities, and broaden their minds. The education system in the pesantren can offer valuable programs to support for this career development.
\end{abstract}

Keywords: women writers, pesantren tradition, 'ulamā',

\section{Introduction}

The publication of popular pesantren novels in recent years in Indonesia signifies the emergence of a new generation of women writers from the pesantren tradition who are influenced by chick lit and

\footnotetext{
1 The earlier version of this paper was presented at The $12^{\text {th }}$ Annual International Conference on Islamic Studies (AICIS), held by the Ministry of Religious Affairs and the State Institute of Islamic Studies (IAIN) Sunan Ampel, Surabaya, 5-8 November 2012.
} 
teen-lit novels. Although these young women writers still need to develop their writing, they fill significant roles in the area of pesantren and Indonesian literature. ${ }^{2}$ These novels are a way for pesantren culture to interact with "outsiders"- those who do not share the pesantren tradition. Outsiders can read, learn about, discuss, and even criticize pesantren knowledge and traditions through this literature. In addition, these young writers can be viewed as representing a regeneration of women's writing from the pesantren, following a tradition represented by earlier writers such as Abidah El-Khaliqy. Their emergence has opened a new window for the development of authorship in the pesantren tradition, which has been dominated by men for many decades. $^{3}$

Through pesantren pop literature, the members of this new generation are building their identity as writers, sharpening their writing skills, and gaining experiences and confidence as they reach toward attaining the quality of serious literature. ${ }^{4}$ Because it is important to support this continuation of women writers from the pesantren tradition, this paper examines their emergence in an effort to determine factors, including family assistance, self-esteem establishment, and schooling, that may encourage or discourage them, and also considers some programs to support and develop the skills they need to achieve careers as writers. I argue that these young women writers are not born from random circumstances but emerge in an atmosphere that supports their efforts to be acknowledged as writers. Furthermore, the environments in which they are schooled strongly influence their self-esteem and can build the foundation of skill and talent they require to be writers. A

2 Compare with Nor Ismah, "The New Generation of Women Writers from the Pesantren Tradition,” Explorations, 11, no. 1 (Spring 2011): pp. 106-120.

3 From the 1960 s to the 1990 s, there were a number of male writers from the pesantren tradition such as Djamil Suherman, Syu'bah Asa, and Fudoli Zaini. They explored the pesantren tradition in their works. However, Abidah El-Khaliqy was the only woman acknowledged as a writer from the pesantren tradition during this period. Ismah, "The New Generation," p. 107.

4 This statement is based on the idea that the "pesantren pop novel is an embryo for sastra pesantren in which the older generation of women writers will be followed by a new generation, while young women writers can develop and improve their talent expressing their experiences using their own language. Therefore, pesantren pop novel can provide a training ground for young writers to develop writing skills which will help promote the introduction of women writers in Indonesian literature." Ismah, "The New Generation,” p. 118. 
supportive pesantren tradition can provide schooling that produces confident women writers who will continue the writing tradition in pesantren and bring out their voices on Islam to young readers.

The best method to answer my research question has been indepth interviews with several young female writers from the pesantren tradition: Jazimah al-Muhyi, Pijer Sri Laswiji, Rida Fitria, Ana FM, Ma'rifatun Baroroh, and Ully Maftuhah. I selected the writers based on three criteria in order to establish a basis for comparison. First, they have all published literary works such as novels or short story collections in the 2000s. Second, they have lived in the pesantren. Third, they all have connections with Yogyakarta because they published their works there. Yogyakarta is a special region located in central part of Java and considered as "cultural capital" of Javanese, an Indonesian's ethnic majority. There are twenty seven publishers in Yogyakarta that associated with IKAPI (Ikatan Penerbit Indonesia, Indonesian Publisher Associations). ${ }^{5}$ With this number of publishers for a small town like Yogyakarta, writers may be interested in publishing their works and got involved with a number of communities of writers such as Matapena and Forum Lingkar Pena. Matapena community, which most of writers I interviewed become members, was established and developed in Yogyakarta. In addition, I also investigated the environments of two pesantren in the Yogyakarta area where two of my interviewees, Pijer Sri Laswiji and Jazimah al-Muhyi, studied. These two pesantren are (1) Nurul Ummah, which has 253 female students and is co-ed (although classes for male and female students are held separately); and (2) Kompleks Q, which has 232 female students. I looked at the differences between them in terms of support for female education, particularly for talented female writers. ${ }^{6}$

The first section of this paper provides a brief description of the writing tradition in the pesantren. It examines how the writing tradition has been developed in the pesantren. The next section describes women's involvement in writing in pesantren and explores some

\footnotetext{
${ }^{5}$ Krishna Sen and David T. Hill, Media, Culture and Politics in Indonesia (New York: Oxford University Press, 2000), p. 16 and p. 26.

6 At least one study has found that education with all-female students gives more advantages to female students than a co-education system in terms of academic achievement. Polly Curtis, "Girls Do Better without Boys, Study Finds," The Guardian (2009). http://www.guardian.co.uk/education/2009/mar/18/secondary-schools-girlsgcse-results (Accessed on 29 July 2011).
} 
differences between older generations and the new generation, and then moves on to focus on several young women writers from the pesantren tradition and the two pesantren in Yogyakarta. In analyzing these writers' experiences, I try to determine family assistance, environments, and schooling factors that have had significant influences on their careers, as well as looking for evidence of an educational atmosphere in which talented girls are encouraged. The paper concludes with the proposal of various steps that could be considered by pesantren in order to support an ongoing regeneration of women's writing.

\section{The Pesantren and Writing Traditions}

Writing and authorship play important roles in spreading Islamic thought and traditions. As suggested by van Bruinessen, the works that form the foundation of Islamic tradition were written between the tenth and fifteenth centuries, and before that period only a small number of significant references were composed. ${ }^{7}$ Core Islamic thought had been accomplished by the end of the fifteenth century, and after that no important elaboration followed. The writing tradition in the pesantren, influenced by the link between Indonesian 'ulamā', (Islamic scholars) and scholars from the Middle East, has strengthened from the nineteenth century onwards from a basis established in the seventeenth and eighteenth centuries. ${ }^{8}$ Nawawi al-Bantani (d. 1896-7), Ahmad Khatib (d. 1915), and Kyai Mahfuz Termas (d. 1919-20) are the three most prominent 'ulama', who studied in Mecca and then taught there in the Masjid al-Haram; through their writings they influenced and inspired the 'ulama' ' of pesantren in Indonesia. ${ }^{\text {? }}$

In the pesantren tradition, the works of these intellectuals are considered Islamic classical texts and called kitab kuning ${ }^{10}$ (yellow

\footnotetext{
${ }^{7}$ Martin van Bruinessen, "Pesantren and Kitab Kuning: Maintenance and Continuation of a Tradition of Religious Learning," in Wolfgang Marschall (ed), Texts from the Islands: Oral and Written Traditions of Indonesia and the Malay World, Ethnologica Bernica, Vol. 4 (Berne: University of Berne, 1994), p. 14.

8 Abdurrahman Mas'ud, Intelektual Pesantren, Perbelatan Agama dan Tradisi (Yogyakarta: LKiS, 2004), p. 85.

${ }^{9}$ van Bruinessen, "Pesantren and Kitab Kuning," p. 20.

10 They are called kitab kuning because of "the tinted paper of books brought from the Middle East in the early twentieth century." Martin van Bruinessen, "Kitab Kuning: Books in Arabic Script Used in the Pesantren Milieu (Comments on a New Collection
} 
books), a term that refers to "classical texts of the various Islamic disciplines, together with commentaries, glosses, and super commentaries on these basic texts written over the ages". ${ }^{11}$ These works demonstrate that writing is part of the pesantren tradition because they were written by scholars from the pesantren and are learned and rewritten by people in the pesantren. The production of works from kyai of the pesantren continues into the twentieth-first century, and most of the works relate to Islamic knowledge, either for education or devotional purposes.

Most critics believe that sastra pesantren (pesantren literature) ${ }^{12}$ must represent and obey Islamic and pesantren values. ${ }^{13}$ Accordingly, starting in the 1960s, several literary works on the pesantren, such as the work of Djamil Suherman and Syu'bah Asa, addressed the religious manifestation and expression of love for God, which was connected with esoteric experiences, human ethics, and the glorification of God's universe. However, in the new genres that have emerged since 2005 in Indonesia, sastra pesantren has expanded from the original form and content. One new genre is subversive literature, which explores stories that contradict pesantren values and traditions. According to Bukhory (2009), this genre is considered a rebellion from the rigidity of religious lessons based on scriptural textbook. It is represented, for example, by Mairil (2005), written by Syarifuddin, that exposes homosexuality in the pesantren with detailed descriptions. ${ }^{14}$

A second new genre is sastra pop pesantren, novels by pesantren alumni that are influenced by the urban genres of chick lit and teen lit.

in the KITLV Library)," Bijdragen tot de Taal-, Land- en Volkenkunde 146 (1990), pp. 226269.

${ }^{11}$ van Bruinessen, "Pesantren and Kitab Kuning," p. 1.

12 Jamal D. Rahman suggests three characterizations of sastra pesantren: first, the literature subsists and widens in pesantren, such as syair and nazham (poems in Arabic language); second, the literature is written by people who have experiences living in the pesantren tradition, for instance kyai and santri; third, the literature concerns knowledge and traditions associated with the pesantren. These three characterizations have opened opportunities to expand sastra pesantren from its original appearance and substance. Jamal D. Rahman, "Sastra, Pesantren, dan Radikalisme Islam,” http://jamaldrahman.wordpress.com/2008/10/25/sastra-pesantren-dan-radikalisme-islam/ (accessed 28 July 2011).

13 Ridwan Munawar, "Ledakan Sastra Pesantren Mutakhir: Cinta, Kritisisme dan Industri," Suara Karya Online, Saturday, March 3 (2007). http://www.suarakaryaonline.com/news. html?id=167741 (accessed 28 July 2011).

14 Ibid. 
These have different themes and styles from the works of the previous generation; and because they address young readers, they use the language and perspectives of contemporary young adults to deliver the story. Writers who represent this new generation include Ma'rifatun Baroroh, author of Santri Semelekete (A Troublemaker) and Pijer Sri Laswiji with Kidung Cinta Puisi Pegon (Love Song from Pegon Poem). ${ }^{15}$ This generation presents a number of young women writers from pesantren as well, and signifies the emergence of women voices through the writing tradition.

In contemplating the pesantren writing tradition, we see that authorship is a continuing process, meaning that new generations of writers continuously emerge, influenced by the trends of their times. However, from the eighteenth to the current century, the number of women writers who have been acknowledged as historically important is much smaller than the number of men writers. Women have not played an important role in creating texts and references in the pesantren tradition. Therefore, it is worthwhile to consider the factors that have influenced this state of things, in order to work toward better balance.

\section{Women Writers from the Pesantren Tradition}

A discussion of women and the pesantren always raises the problematic issues. There are numerous interpretations of Islam regarding women's position in society, but in general, they locate women as being under men's domination. This helps to explain why Indonesian women gained access to education in the pesantren only in the early twentieth century, starting from Pesantren Denanyar in Jombang in $1930,{ }^{16}$ even though pesantren have existed at least since the pre-eighteenth century as a teaching group. In addition, limitations have been placed on women's roles in the pesantren. For example, the privilege of being nominated as a future leader is possible for the son but not the daughter of a kyai. If the kyai does not have a son, then his son-in-law will receive the position. In teaching activities, female

\footnotetext{
15 Ibid.

16 In 1930, a formal pesantren for girls was established in Pesantren Denanyar, but it was begun as an informal class in 1919 in the backyard of Kyai Bisri's ndalem (house of a kyai). Eka Srimulyani, "Negotiating Public Space: Three Nyai Generations in a Jombang Pesantren," in Susan Blackburn, Bianca J. Smith and Siti Syamsiyatun (eds), Indonesian Islam in a New Era: How Women Negotiate Their Muslim Identities (Victoria: Monash University Press, 2008), p. 137.
} 
instructors-nyai (the wife of the kyai), ning (the daughter of the kyai), and ustadzah (female instructor) —are forbidden to teach male santri. ${ }^{17}$

Due to such restrictions, pesantren women do not have as wide a role as men. However, a study conducted by Srimulyani (2008) on three nyai generations in Pesantren Seblak, Jombang has concluded that gender relations in the pesantren are simultaneously processes of negotiation and change. Gender relations are not simply classified with public space being associated with men and private space with women, but are influenced by how well these women can negotiate their positions in their lives, families, and the structural organization of the pesantren or madrasah. For instance, Nyai Khoiriyah, born in 1906, was a nyai in Pesantren Seblak in Jombang who was not only regarded as ulama, a label that normally is assigned to male scholars, but was also as a writer. One of her notable published articles is "The Islamic School and its Tolerance". ${ }^{18}$

In addition to Srimulyani's work, however, there is no record detailing when women pesantren began their involvement in authorship and what kind of works they have written. Yet it is important to investigate the existence of women writers from the pesantren tradition to reveal women's participation in creating religious texts, a genre written by kiai from the seventeenth and eighteenth centuries such as Nawawi al-Bantani (d. 1896-7) and Ahmad Khatib (d. 1915) and many other type of publications. Moreover, pesantren women have long contributed to pesantren education alongside their male counterparts, but they have been neglected by history. It is surely time for this oversight to change and for us to acknowledge their past contribution, resurrect their history and support a more equitable and encouraging environment. Therefore, research and discussion that helps women emerge into greater prominence is important.

Abidah El-Khaliqy, who is respected as the most prominent woman writer from the pesantren tradition, started to be known in the mid-1990s when her work was published for the first time. She prompted people to consider her involvement in writing and Indonesian literary field by bringing ideas rooted in the pesantren

${ }^{17}$ Eka Srimulyani, "Negotiating Public Space: Three Nyai Generations in a Jombang Pesantren," in Blackburn, Smith, and Syamsiyatun (eds), Indonesian Islam in a New Era, pp. 120-1.

18 Ibid., p. 119 and pp. 126-7. 
tradition. ${ }^{19}$ While Abidah El-Khaliqy acts as a bridge between the world of the pesantren and that of outsiders, in a similar fashion, many of the young women writers who appeared at the beginning of the twenty-first century have the same interest in exploration. This new generation is influenced by the publication and translation of chicklit and teenlit ${ }^{20}$ in Indonesia, however, this generation uses young people's language to explore the pesantren world. 21

In the following section, the experiences of some women in pursuing their careers as writers: Jazimah al-Muhyi, Pijer Sri Laswiji, Rida Fitria, Ana FM, Ma'rifatun Baroroh, and Ully Maftuhah will be examined. Not all of these writers are generally known by readers in Indonesia, but they are important in maintaining the writing tradition in pesantren, and beyond that, in making position of women better recognized. They represent a new position of women emerging from the pesantren, as writers who can confidently share their experiences and views on the pesantren and the Islam. Thus, academic discussions should encourage such voices to succeed.

\section{Personal Initiative; the Most Influential Factor in Becoming Writer}

In terms of women's achievements, Peacock has pointed out that initiative and independent decision-making are two areas women should focus upon in order to achieve their career goals. ${ }^{22}$ This means that women "make their own life choices and voice their own desires and protests" 23 or, according to bell hooks, have "the ability to act in

19 Diah Ariani Arimbi, Reading Contemporary Indonesian Muslim Women Writers: Representation, Identity and Religion of Muslim Women in Indonesian Fiction (Amsterdam: ICAS Publications Series, Amsterdam University Press, 2009), p. 95 and p. 98.

20 This genre tells about "stories of young cosmopolitan working women aged in their twenties or thirties concerned with issues such as fashion, shopping and sex. Search for 'Prince Charming' Diah Ariani Arimbi, Reading Contemporary Indonesian Muslim Women Writers: Representation, Identity and Religion of Muslim Women in Indonesian Fiction (Amsterdam: Amsterdam University Press, ICAS Publications Series, 2009), p. 83.

${ }^{21}$ Ismah, The New Generation of Women Writers.

${ }^{22}$ James Peacock, "Introduction," in Javanese Lives Women and Men in Modern Indonesian Society (New Brunswick and London: Rutgers University Press, 1991), p. 7.

${ }^{23}$ Rosemary Roberts and Helen Creese, "Gender, Text, Performance and Agency in Asian Cultural Contexts," Intersections: Gender and Sexuality in Asia and the Pacific, Issue 16, March (2008). 
[their] best interest". ${ }^{24}$ This is the frame in which feminists believe and in which they work. ${ }^{25}$ Therefore, although in many cultures women generally are in very disadvantaged positions, some of these women find ways to break the pattern and demonstrate their existence in their field of interest. ${ }^{26}$

Underlining these ideas, all the young women writers mentioned above made progress in their writing, often beginning in childhood. Rida Fitria (the pen name of Nur Rida Fitria), for example, who wrote Sebongkah Tanah Retak (One Piece of Cracked Soil) (2010), began to write down her questions and feelings in order to stop questioning her mother about everything. She loved reading to find answers to her questions, and from this habit she also became used to writing. ${ }^{27}$ Similarly, Jazimah Al-Muhyi, who has the given name Siti Jazimah, was able to access many readings such as newspapers and magazines in her home, and this helped her learn that she could express her ideas through writing. She likes writing poetry and word composition and is today the author of seventeen books. ${ }^{28}$ In addition to these writers, Pijer Sri Laswiji, ${ }^{29}$ Ully Maftuhah, ${ }^{30}$ Ana FM, ${ }^{31}$ and Ma'rifatun Baroroh $^{32}$ also began their writing hobby with a reading hobby.

For these young women, reading stimulated their writing skills, during their childhood when still under their parents' guidance. However, this does not mean that their interests and talents were generated by their parents. Furthermore, none of these writers have parents who are writers. Specifically, Ma'rifatun Baroroh, author of Santri Semelekete (2005), gained no assistance from her parents. Born in 1986 and from an ordinary family, Baroroh had to make a strong effort to find reading material, using her initiate to collect used children's

\footnotetext{
24 Bell Hooks, Yearning: Race, Gender and Cultural Politics (Boston: South End Press, 1990), p. 206.

25 Roberts and Creese, "Gender, Text, Performance".

${ }^{26}$ Peacock, "Introduction," p. 7.

27 Rida Fitria, email, 8 July 2011.

28 Jazimah Al-Muhyi, email, 5 July 2011.

29 Pijer Sri Laswiji, interview, 11 July 2011.

30 Ully Maftuhah, interview, 10 July 2011.

31 Ana FM, interview, 10 July 2011.

32 Ma'rifatun Baroroh, interview, 11 July 2011.
} 
magazines from her friends. ${ }^{33}$ Therefore, it can be said that all of these writers decided their own way of becoming writers, and this was maintained when they continued their studies in the pesantren. In other words, personal initiative seems to be the key aspect in their achievement as writers, while assistance and facilities provided by the family helped stimulate and support them.

Many young women writers have overcome some of the obstacles that might appear to exist in the pesantren environment and have made this experience part of their continuing progress. Becoming a writer requires a continuing process, with regular self-training and decisions about possible ideas and topics on which to write. ${ }^{34}$ Indeed, these are challenges that were faced by these young women writers when they continued their studies in the pesantren. Ully Maftuhah, the writer of Blok I (Unit I) (2009), which explores the experiences of new santri in the pesantren, said that when she feels unable to develop new ideas, she asks permission from the pesantren board members to go out into the town. Then she will sit for a long time, observing objects and events in the street as a way of focusing her view in order to learn about and contemplate characters for her story. Furthermore, because her pesantren does not provide computers, she writes her work out by hand, typing it later when she is at home..$^{35}$

The "ability to act in one's best interest" is also shown by Rida Fitria, who published her novel Bunga dan Duri (Flower and Thorn) (2011) in Yogyakarta. When she was in the pesantren, she had time to develop her writing hobby, but now she has to take care of her children, manage her family business, and stay involved with a community of art and culture for whose members her house has become a base camp. However, she still keeps writing, and moreover, feels that her husband understands and supports her. ${ }^{36}$ In a similar fashion, Jazimah, who was born in 1979, has to take care of three children, and was pregnant at the time of our interview. She states that she must build the spirits of her children and wishes for blessings from God so that He may strengthen her to be productive. In the beginning

\footnotetext{
${ }^{33}$ Ma'rifatun Baroroh, interview, 11 July 2011.

34 Steve Peha, "Welcome to Writer's Workshop," www.ttms.org (accessed 25 July 2011)

35 Ully Maftuhah, interview, 10 July 2011.

36 Rida Fitria, email, 8 July 2011.
} 
of her life as a wife and mother, her productivity decreased, but now she has adjusted to the number of responsibilities. ${ }^{37}$

According to Streit, ${ }^{38}$ the way in which women attain achievements in their career can be affected by the support of their family. Research ${ }^{39}$ has shown that the degree to which husbands support their wives' choice of profession can determine the self-esteem of the wives, and that this type of support is necessary for women's career sustainability. In addition, community support is crucial for those who live outside creative writing environments such as pesantren. However, Ana FM, born in 1988, argues that although the environment, (meaning both family and community), is important to support a writers' productivity, initiative still plays a significant role in a person's ability to become a writer. "I noticed this from some writers who are still productive though they are in a jail or in a place where there are no facilities, such as Pramodya Ananta Toer. So, in my opinion, we must build our initiative, then we can develop our skills through the environment," Ana explained. ${ }^{40}$

On the basis of comments from these writers, it is evident that each of them has developed an identity as a writer, and attempts to maintain it through making their on-going choice of profession. The ability to choose and establish their identities has fostered their self confidence and it is important for their self-esteem. As Renshaw argues, "To feel proud of ourselves, to believe in ourselves, to feel happy with ourselves... from such a well-spring of self-esteem, decisions and actions will flow, which promote our real interests and

\footnotetext{
${ }^{37}$ Jazimah Al-Muhyi, email, 5 July 2011.

38 Ursula Streit and Yolande Tanguae, "Professional Achievement, Personalty Characteristics and Professional Women's Self-Esteem," in Joanne. Gullivan, Sharon Diane Crozier and Vivian M. Lalande (eds), Women Girls and Achievement (Ontario: Captus University Publications, 1994), p. 64.

39 A research is done by Noraini M. Noor. From a sample of 153 employed married women in the University of Oxford, her research concluded, "Wives' estimates of their husbands' time spent doing housework is a better predictor of their distress symptoms than estimates of their own time spent doing housework. Further, the relationship between wives' estimates of their husbands' time spent doing housework and their distress scores is mediated by perceived support." Noraini M. Noor, "The Relationship between Wives' Estimates of Time Spent Doing Housework, Support and Wives' Well-being," Journal of Community \& Applied Social Psychology, Vol. 7 (1997): pp. 413-423.

40 Ana FM, interview, 10 July 2011.
} 
welfare." 41 The acknowledgment of oneself through such self-defining affirmations as "I am a girl, a child, a black, an Australian" creates "social groupings" and positions the emerging self-concept within them. Therefore, each person learns simultaneously about "the self and the society." The power and status of the self-concept that develops is influenced by the power and status of the social grouping. From this view, then, there is clear interconnection between "social change and individual change". 42

Furthermore, relations with external influences and how someone thinks about self determine "identity, self-concept, and self-esteem." That means that someone's self-esteem is associated with the harmony between "their feelings about themselves and those provided by significant others;" moreover, achieving some feeling of unity in the numerous messages individuals accept is important. ${ }^{43}$ Based on this idea, the personal initiative of these young women writers has helped build and determine their identity, self-concept, and self-esteem, while also creating their social grouping as writers. In order to sustain and strengthen these three aspects, it is necessary to strengthen the social grouping as well.

\section{Self-Esteem and Learning Environment: The Atmosphere in which the Writer Grows Up}

Self-esteem is "an effective response to the self as an object, deriving from complex cognitive and emotional interpretations of selfrelevant information generated through action and interaction in the world". ${ }^{44}$ According to Tsolidis, self-esteem is connected to the capability to influence one's own future. A positive connection between self-esteem and achievement has been found consistently. Although it is possible that in certain areas self-esteem is not

41 Peter Renshaw, "Self-Esteem Research and Equity Programs for Girls: A Reassessment," in Jane Kenway and Sue Willis (eds), Hearts and Minds: Self-Esteem and the Schooling of Girls (Bristol PA: The Falmer Press, 1990), p. 23.

42 Ibid., p, 23.

${ }^{43}$ Pat Dugdeon, Simone Lazaroo, and Harry Pickett, “Aboriginal Girls: Self-Esteem or Self-Determination," in Kenway and Willis (eds), Hearts and Minds, p. 75.

${ }_{44}$ M.L., V. Gecas Schwalbe and R. Baxter, "The Effects of Occupational Conditions and Individual Characteristics on the Importance of Self-Esteem Sources in the Workplace," Basic and Applied Social Psychology 7 (1986), p. 64. 
connected to one's actual achievement, the connection is reasonable and is not just an assumption. ${ }^{45}$

The self-concept and self-esteem of young women writers from the pesantren tradition is supported by the family, the environment where they were stimulated to develop a reading habit. Most of the writers I interviewed, with the exception of Ma'rifatun Baroroh, share the same experience of knowing about reading material, drawing, and casual writing for the first time in the family environment. This is especially true in the case of Jazimah Al-Muhyi, whose father strongly suggested that she read newspapers, magazines, and serious books. He even did not allow her to play, and her mother always reviewed her notes when she returned from the school, making sure that she took notes properly. Due to this regular supervision, Jazimah became used to writing down whatever her teacher said in the class. ${ }^{46}$ While Ana FM's parents did not provide books and magazines, she had the privilege of not assuming household responsibilities, like cooking and cleaning, due to her focus on reading. "They let me make my own decision to improve my talent," she said. ${ }^{47}$

However, some of the writers argue that the family environment could potentially provide more support than they received. For example, Ully Maftuhah, born in 1984, suggests that besides giving support through "positive words" such as "you should write" and "I am proud of you" - kind words that Ana FM did not receive from her parents-parents or other members of the family could help connect the writer to publishers or other outlets. "They also could give suggestions and comments when I am discussing or bargaining with a medium of publication. However this did not happen, and so far I have felt alone in this process," Ully explained. 48 Other writers such as Pijer Sri Laswiji, Ana FM, and Ma'rifatun Baroroh make the same recommendations, although they generally understand that because of the background of their families, who are not writers, there is a lack of sufficient experience to support the talents and interests of their

\footnotetext{
45 Georgina Tsolidis, "Ethnic Minority Girls and Self-Esteem," in in Kenway and Willis (eds), Hearts and Minds, p. 63.

46 Jazimah Al-Muhyi, email, 5 July 2011.

47 Ana FM, interview, 10 July 2011.

48 Ully Maftuhah, interview, 10 July 2011.
} 
children. "It is not a big deal for me because my parents did not go to school, and I can make the effort by myself," Baroroh emphasized. ${ }^{49}$

Indeed, while the family provides the environment that supports the development of their children's interests and for building their selfesteem, the learning environment in the pesantren can be even more beneficial. This is in line with Wenner's claim that generally people are more encouraged by cultural traditions to distinguish themselves primarily as part of a family unit, rather than as an individual, and that this cultural perception affects the significance of the self-esteem concept. ${ }^{50}$ Therefore, when students are living in an environment that gives them distance from the family, such as pesantren or boarding school, they can become involved with their personal life as an actualized experience. ${ }^{51}$ The establishment of self-esteem then becomes more relevant, as they can decide on and act to pursue their own goals. As an example, Rida Fitria says that living in the pesantren is different from any other boarding school because each pesantren has its own style and rules. She feels that "time cannot determine my life, but I myself can. In the pesantren, I learned how to be consistent and creative so that I can still enjoy living there with the same activities the whole day, the whole year. I also learned how to appreciate my life and to be myself." 52

Ana FM began writing professionally when she was in senior high in the pesantren. One of her friends was a writer, and she was inspired to write a novel. "She can write, so I also can do the same thing," Ana thought. She made the attempt, writing her first work by hand, and after finishing it, she read it to her friends. Surprising her, one of her friends went to the kyai and informed him about Ana's talent. He encouraged Ana, even connecting her to a publisher. ${ }^{53}$ In a similar experience, Ully started writing seriously because of the inspiration of one of her pesantren friends, who modified a story from a magazine with her own idea and characters. She used to write short stories, even writing three stories in one day. "I became very productive in the

\footnotetext{
${ }^{49}$ Ma’rifatun Baroroh, interview, 11 July 2011.

50 Jackie Wenner, "Culture, Gender and Self-Esteem: Teaching Indo-Chinese Students," in in Kenway and Willis (eds), Hearts and Minds, p. 111.

${ }^{51}$ V. D. Le, "Please Understand Me-Xin Hiu Toi” Pivot 13, No. 5 (1986), p. 41.

52 Rida Fitria, email, 8 July 2011.

53 Ana FM, interview, 10 July 2011.
} 
pesantren. It may have been motivated by my friends. They always asked me to write and were curious about the ending of my stories when I had not finished the work," Ully states. ${ }^{54}$

The pesantren is important in providing a learning environment where young women writers can strengthen their self-esteem. For example, they are involved with a community of writers that is facilitated by the pesantren. They meet friends with the same ideas and interests in this community, make a social grouping, and strengthen their identities as writers and artists. Pijer Sri Laswiji, born in 1983, was inspired by Jamal D. Rahman, a prominent male writer from the pesantren tradition. He came to her pesantren in Surakarta, Central Java, with several writers from Horizon magazine to take part in a program. Jamal D. Rahman read his poetry for the students, and after that Pijer attempted to write poetry. Eventually, she was able to send three poems to Horizon, and this motivated her to be more active in creative writing. She became involved with Al-Mansur, a school magazine, and El-Majazi, a notice board in her pesantren. Later, when she moved to Pesantren Nurul Ummah in Yogyakarta, she became involved with Tilawah magazine, Assabiq notice board, and the Sahara community. ${ }^{55}$

In addition to pesantren, the learning environment of the community of writers plays a significant role in sustaining self-esteem when the writers have graduated from the pesantren. Ully Maftuhah took the initiative to become involved with Ikatan Penulis Muslim Wonosobo (IPMW, the Association of Muslim Writers in Wonosobo, Central Java) after she left the pesantren. They have programs once a week discussing members' work in order to provide feedback and comments. ${ }^{56}$ Similarly, while taking care of her children, Baroroh joined the Matapena Community in Yogyakarta. Though she thinks that she cannot only focus on writing because of her responsibilities as a mother, she finds advantages in being involved with a community, gaining friendship and motivational influence from other writers. ${ }^{57}$ In like manner, Jazimah has received significant influence since becoming involved with Forum Lingkar Pena (FLP, Pen Circle Forum), because it is a collaboration between writers and publishers. "I have improved

\footnotetext{
54 Ully Maftuhah, interview, 10 July 2011.

55 Pijer Sri Laswiji, interview, 11 July 2011.

56 Ully Maftuhah, interview, 10 July 2011.

${ }^{57}$ Ma'rifatun Baroroh, interview, 11 July 2011.
} 
my career fast. Sometimes we write one book together. That's FLP, and I think I would not have been able to reach this position without FLP," she explains. ${ }^{58}$

Contemplating their self-esteem and the learning environments experienced by all these young writers, I observed that they all develop within two different learning environments. First is the homogenous environment in which they meet and interact with people of the same gender, concerns, and culture. This is represented by family and the pesantren, though it is possible to communicate with people of different genders and backgrounds in both environments. Second is the heterogeneous environment where they can meet with various types of people. Ully Maftuhah underlines that she had to adjust to a new and wider environment when she became involved with IPMW because it is a heterogeneous environment. The advantage that she feels she has gained is that it broadens her mind, from the closed pesantren and Islamic thought to secular and multicultural thought. ${ }^{59}$ Engaging with a community focused on migrant domestic workers in Lumajang East Java, Rida Fitra finds that there are a number of young people who are concerned about unfamiliar but significant issues. ${ }^{60}$

Based on young women writers' experiences, self-esteem and learning environment have influenced their career achievement. According to Peter Renshaw, it may be true that achievement can be affected by self-esteem, but contemporary studies argue that "changes in self-esteem follow rather than precede achievement." 61 This statement underlines the significance of observing the quality of education and the resource allocation for women, instead of focusing on an assumption of inadequacy among individual girls.

\footnotetext{
58 Jazimah Al-Muhyi, email, 5 July 2011.

59 Ully Maftuhah, interview, 10 July 2011. In addition to Maftuhah, other writers such as Ana FM, Ma'rifatun Baroroh, Jazimah al-Muhyi, and Pijer Sri Laswiji also felt that pesantren circumstances are somehow closed. In regard to creative writing activities, they lack wider access and opportunities for involvement with outside programs or communities. "So, when I move from the pesantren, I feel free and get freedom to attend any activities and trainings related to creative writing," Jazimah says.

${ }^{60}$ Rida Fitria, email, 8 July 2011.

${ }^{61}$ Renshaw, Self-Esteem Research and Equity, p. 31.
} 


\section{Pesantren Education that Considers Writing Skills}

All these young women writers suggest that the pesantren where they lived for several years did not provide a solid system of education to be a writer, because the concern of pesantren is Islamic teaching. Improvement in writing skills is considered an individual choice and must be attempted by each santri. However, many pesantren still do consider, and even encourage, the development of writing skills by providing some relevant activities and programs. According to Baroroh, who studied in Pesantren an-Nur in Yogyakarta for six years, writing skills were not taught as a subject in her pesantren, which focused on memorizing the Qur'an. In such an education system, it is no wonder that she did not find any support for developing her writing skills. It took a long time for her to succeed in having a short story published by a magazine. Yet when the story with her name on it appeared, the pesantren board members realized the importance of writing as a way of sharing ideas through publication. They began to conduct journalistic training for pesantren students, and they also established a notice board and a pesantren library. ${ }^{62}$

Jazimah al-Muhyi and Pijer Sri Laswiji had more fortunate experiences because their pesantren had programs for improving writing skills that fostered student talent and interest. Jazimah studied in Kompleks Q, one unit of Pesantren al-Munawwir, located in Krapyak, Yogyakarta. It was established by KH. Ahmad Warson Munawir in 1989, and dedicated for only santri puteri (female students of pesantren) who want to gain Islamic knowledge while attaining formal education outside the pesantren. ${ }^{63}$ In 2011, a total of 232 female santri studied in this pesantren. ${ }^{64}$ In a different place, Pijer studies in Pesantren Nurul Ummah, located in Kotagede, Yogyakarta. It was established by $\mathrm{KH}$. Marzuki in 1986. Although Nurul Ummah accepts both male and female students, and locates them in different buildings, the focus of learning is similar to that at Kompleks Q, which is the learning of

\footnotetext{
${ }^{62}$ Ma'rifatun Baroroh, interview, 11 July 2011.

63 Djunaidi A. Syakur, Buku Panduan Pondok Pesantren Putri Al-Munawwir Krapyak Yogyakarta Madrasah Salafiyah III (Yogyakarta: Pengurus Madrasah Salafiyah, 2010/2011), pp. 10-11.

${ }^{64}$ Siti Sobariah, interview, 18 July 2011.
} 
classical Islamic knowledge and formal education attainment for the students. ${ }^{65}$

In the same way, Rida Fitria, ${ }^{66}$ Ana FM, ${ }^{67}$ and Ully Maftuhah ${ }^{68}$ studied in pesantren that gave some attention to developing writing skills. Through programs offered by pesantren board members, they found a learning environment that encouraged their talent. The programs included the publication of magazines, news paper, and notice boards, normally coordinated under Lembaga Penerbitan Santri (Student Publishing Organization). They also included events related to creative writing such as book discussions and journalistic training, and creative writing communities. Furthermore, Ana FM studied in a pesantren known as a place of writers-Pesantren An-Nuqayah, located in Sumenep, Madura. Although writing skills are not the focus of its education system, according to Ana, the learning environment is well organized to appreciate and encourage students' writing interests. Therefore, she believes that Pesantren An-Nuqayah is an ideal pesantren for creative writing improvement. ${ }^{69}$

Even when a pesantren establishes programs in creative writing improvement, however, it does not necessarily mean that all the programs are well applied. These young women writers state that the value of these programs depends on several factors such as facilities, human resources, and the awareness of pesantren board members. For example, Pijer Sri Laswiji, the author of Coz Loving U, Gus (2006), thinks that pesantren limitations on using electronic equipments, especially computers, do not encourage students to be productive. Certainly, pesantren provide computer rental, but it is limited. ${ }^{70}$ Similarly, Ully Maftuhah criticizes student press organizations because they do not play a significant role in maintaining student interest in creative writing, such as by conducting creative writing training. They just publish magazines in a process dominated by senior students. "In my

\footnotetext{
${ }^{65}$ Situs Resmi Pondok Pesantren Nurul Ummah. "Peraturan Dasar Pondok Pesantren Nurul Ummah Putri Kotagede Yogyakarta.” http://www.nurulummah.com/blank.php?tentang=tentangppnu/ad_art_pi.html (accessed on 25 July 2011).

${ }^{66}$ Rida Fitria, email, 8 July 2011.

${ }^{67}$ Ana FM, interview, 10 July 2011.

${ }^{68}$ Ully Maftuhah, interview, 10 July 2011.

${ }^{69}$ Ana FM, interview, 10 July 2011.

70 Pijer Sri Laswiji, interview, 11 July 2011.
} 
opinion, it would be better if pesantren created a system of education with supporting facilities for being a writer. Moreover, pesantren should provide a special room for those who are interested in writing," Ully suggests. ${ }^{71}$ In addition, Jazimah emphasizes the pesantren's potential role in providing resources such as magazines and books, as well as in connecting writers from the pesantren with publishers in order to assist them in both publishing their work and having access to other opportunities such as being a translator. ${ }^{72}$

Agreeing that these problems occur in the pesantren, Robithoh Widiastutik, a board member of Pesantren Nurul Ummah, explains that most pesantren board members are more concerned with the compulsory programs, such as diniyah, Islamic classical text recitation, and Qur'an memorization. Although the nyai of Pesantren Nurul Ummah allows and even encourages the students to maintain their writing interest, the spirit of this program depends on students' initiative. "When Pijer Sri Laswiji was studying here, I could feel the spirit of creative writing. She maintained the Sahara community, ${ }^{73}$ which focuses on creative writing and art performance," Widiastutik said. ${ }^{74}$ Similarly, Siti Sobariah, a chairperson of the Kompleks Q board, thinks that creative writing is an optional activity in the pesantren. Although the kyai does encourage students to write, this is not mandatory. Therefore, most students prefer to focus on the obligatory programs within their limited time. "And I think, although we have allowed student to use laptops in the pesantren, it does not encourage change if the students do not have their own initiative to write," Sobariah emphasized. ${ }^{75}$ As a result, activities and media offered by pesantren are only supporting programs, and students who want to be writers must make their own decisions and efforts to reach their goal, while they build their self-esteem in the pesantren environment.

\footnotetext{
${ }^{71}$ Ully Maftuhah, interview, 10 July 2011.

${ }^{72}$ Jazimah Al-Muhyi, email, 5 July 2011.

${ }^{73}$ Sahara community was established in 2003 in order to support and facilitate creative writing interest in Pesantren Nurul Ummah for female santri. The community began with the publication of a compilation of poetry entitled "Jalalah." (Robithoh Widiastutik, interview, 18 July 2011).

${ }^{74}$ Robithoh Widiastutik, interview, 18 July 2011.

75 Siti Sobariah, interview, 18 July 2011.
} 
Returning to the idea of a continuing writing tradition, pesantren have the opportunity to play important roles in helping the santri to become writers. Moreover, living in the dormitory encourages santri to study intensively. Pesantren can apply a gifted education program according to the student's needs, including writing. However, producing writers is not its key objective, so it may seem unrealistic for pesantren to focus on it. But if they can see the benefits of writing skills, even small changes would be useful for young women. Through writing, young women can develop their analytical skills, interpret their experiences, express their voices, and share their ideas with public readers. These exercises can help them to build their self-esteem, and as a result, young women will feel more confident. In addition, pesantren will have the opportunity to attract various students, some of whom may want to be writers.

Another issue that emerged during my interviews was the idea of same-sex education as regulated by pesantren. The idea that same-sex education promotes better achievement for female students is supported by one study conducted by Carter. ${ }^{76}$ She finds that female students normally show better achievement in science and are more convinced about their ability when they are educated in a same-gender environment. However, according to these young women writers, their male counterparts in the pesantren give them ideas about male worlds that support their exploration when they create male characters. Ully Maftuhah gives an example: "I can write not only about female students, but also male students, of course, because the pesantren programs involve males." 77 Similarly, Ana FM also claims that the environment of the co-ed system of education created no significant problems regarding her achievement. Moreover, male students sometimes are requested to share their experiences in creative writing in front of female students. ${ }^{78}$

Although Kompleks Q is a single-sex pesantren, this does not necessarily mean that students have no interaction with males. Students of Kompleks Q normally attain formal education outside the pesantren where they have the chance to interact with their male

\footnotetext{
76 Tracey-Ann Carter, "The Effect of Single Sex Schooling on Girls' Achievement in Physical Science” (Unpublished MA thesis, University of South Africa, 2005), p. 69.

77 Ully Maftuhah, interview, 10 July 2011.

78 Ana FM, interview, 10 July 2011.
} 
counterparts. ${ }^{79}$ In co-ed Pesantren Nurul Ummah, the male and female students cooperate with each other in certain programs, such as the publication of the pesantren magazine, newspaper, and notice board. Widiastutik provides another example: "The male santri, Kang Zaki is one of our instructors for the Sahara community. We invite him to assist us in discussing creative writing problems." 80 In terms of differentiation of access to opportunity between male and female students, in certain cases, male students are given more flexibility than female students. For example, boys are allowed to carry out any program at night, but female students can only attend programs in the daytime. ${ }^{81} \mathrm{~A}$ male student can give a speech in front of female students, but a female is not allowed to give a speech in front of male students. ${ }^{82}$

On the other hand, in one case, as mentioned by Pijer, ${ }^{83}$ boys and girls have the same opportunities; for instance, they can attend an outside training program by submitting required documents. However, this still does not result in giving completely equal opportunities for both boys and girls. In comparison with male students, female students are still positioned in the second line and none obtain the broad opportunities available to male students. Allowing female students to speak in front of male students would be a significant way of building self-esteem. Pijer says that she feels upset and wonders why female students are not allowed to give presentation in front of male audiences. She thinks that these limitations influence her selfconfidence and her broaden sociability, and as a result, she judges herself as "kurang pergaulan" (less sociable). She shares, "When I was in Solo and I had to speak in front of boys, I felt hard to speak. I had to say bismillah many times. [At that time] I was with Matapena and I gave a presentation about my novels, if the audiences were boys, I felt that. But if the audiences were girls, it was easy to speak." 84 Therefore, developing an education system and a learning environment that consider gender equality and avoid different treatment of male and

\footnotetext{
${ }^{79}$ Siti Sobariah, interview, 18 July 2011.

${ }^{80}$ Robithoh Widiastutik, interview, 18 July 2011.

81 Pijer Sri Laswiji, interview, 11 July 2011.

82 Robithoh Widiastutik, interview, 18 July 2011.

83 Pijer Sri Laswiji, interview, 11 July 2011.

${ }^{84}$ Ibid.
} 
female students are important to support the continuation of women's writing in pesantren.

\section{Conclusion}

The link between Indonesian ulama and scholars from Middle East in the seventeenth and eighteenth centuries has influenced the writing tradition in the pesantren. Nawawi al-Bantani (d. 1896-7), Ahmad Khatib (d. 1915), and Kyai Mahfuz Termas (d. 1919-20) are three influential writers from the pesantren. Their works known as kitab kuning are used as references of pesantren teaching. The production of kitab kuning that relates to Islamic knowledge, either for education or devotional purposes continues into the twentieth-first century. However, most of the writers are males, and very few records provide detail information on women's involvement in authorship, rather than their involvement in education. Abidah El-Khaliqy is the first woman who was known as the most prominent woman writer from the pesantren tradition in the mid-1990s when her work was published.

Following Abidah eL-Khaliqy, there is the new generation of women writers from the pesantren tradition. The emergence of these writers, Jazimah al-Muhyi, Pijer Sri Laswiji, Rida Fitria, Ana FM, Ma'rifatun Baroroh, and Ully Maftuhah, is significant because they give a new color in the history of women's authorship in the pesantren. Based on the experiences of these young women writers, there appear to be a few factors important to all of them. The most influential factor in their achievement is that they have shown initiative in pursuing their careers. They have chosen the identity of writer, and made an effort to preserve it by making their own decision in pursuing this profession.

Self-esteem and learning environments including family and pesantren are important factors in influencing the achievement in writing. Self-esteem is partly developed in a learning environment in which the writers can sharpen their writing skills, strengthen their identities, and broaden their minds. The education system in the pesantren can offer valuable programs to support for this career development. Contrary to the generally accepted view, these limited samples show that co-ed pesantren are more beneficial in terms of career development and improvement in writing skills than is a single-sex program. Male and female students cooperate in certain programs, and due to this cooperation, female writers gain understanding of the male world that supports their character descriptions when they write a 
story. At the same time, however, males and females do not enjoy the same opportunities; thus, in order to better support young women writers' achievement, pesantren programs should develop gender equality.

Although the main purpose of pesantren education is to train the student with Islamic knowledge, according to these young women writers' experiences, programs that support writing skill development in the pesantren are useful in achieving their career as writers. Through writing, they can build their self-confidence, express their ideas about Islam, women, and pesantren, share their experiences, and even help maintain the writing tradition and present pesantren identity to the public readers. Furthermore, supporting writing skill development may help pesantren to attract many students enrolling education in there. Thus, if pesantren could consider a design education appropriate for women writers, it would be advantageous for both the students and pesantren.

There are some specific points derived from these young women's experiences that could be considered by pesantren that wish to support women's writing. First, becoming a writer is a personal decision; therefore every santri must have a solid self-concept, which is important in building strong self-esteem. Second, in addition to Islamic knowledge, pesantren could introduce writing skill development into the pesantren curriculum. This could be considered a compulsory program and a normal part of pesantren activities, not just a recommended program. Third, writing development needs facilities such as libraries and student publications such as magazines. Fourth, the system of coed pesantren where male and female students can work together seems more beneficial to writing skill improvement, but an equal distribution of opportunities must be supported. Fifth, pesantren could take on the role of a bridge that connects writers and publishers and other sources helpful to career development. If pesantren could implement all these recommendations, the future for women's writing would look very bright.]

\section{Bibliography}

\section{Books and Articles}

Arimbi, Diah Ariani. Reading Contemporary Indonesian Muslim Women Writers: Representation, Identity and Religion of Muslim Women in 
Indonesian Fiction. Amsterdam: Icas Publications Series, Amsterdam University Press, 2009.

Bruinessen, Martin van. "Kitab Kuning: Books in Arabic Script Used in the Pesantren Milieu (Comments on a New Collection in the Kitlv Library)." Bijdragen tot de Taal-, Land-en Volkenkunde 146 (1990): 226-69.

-. "Pesantren and Kitab Kuning: Maintenance and Continuation of a Tradition of Religious Learning." In Texts from the Islands: Oral and Written Traditions of Indonesia and the Malay World, Ethnologica Bernica, Vol. 4, ed. Wolfgang Marschall, 121-45. Berne: University of Berne, 1994.

Bukhory, Umar. Spiritualitas Sastra Pesantren sebagai Sub Kultur Sastra Islam. Okara (Volume 1 tahun 4, Mei 2009).

Carter, Tracey-Ann. "The Effect of Single Sex Schooling on Girls' Achievement in Physical Science." MA thesis, University of South Africa, 2005.

Curtis, Polly. "Girls Do Better without Boys, Study Finds." The Guardian (2009). http://www.guardian.co.uk/education/2009/mar/18/secondary-schools-girls-gcse-results_(accessed 25 July 2010).

Dugdeon, Pat, Simone Lazaroo, and Harry Pickett. "Aboriginal Girls: Self-Esteem or Self-Determination." In Hearts and Minds: SelfEsteem and the Schooling of Girls, ed. Jane Kenway and Sue Willis, 71-96. Bristol, PA: Falmer Press, 1990.

Hooks, Bell. Yearning: Race, Gender and Cultural Politics. Boston: South End Press, 1990.

Ismah, Nor. "The New Generation of Women Writers from the Pesantren Tradition in Indonesia." Explorations 11 no. 1 (2011): 106-20.

Le, V. D. "Please Understand Me-Xin Hiu Toi'!" Pivot 13, no. 5 (1986): 40-4.

Liow, Chinyong Joseph. Islamic Education and Reform in Southern Thailand: Tradition and Transformation. Institute of Southeast Asian Studies, 2009

Mas'ud, Abdurrahman. Intelektual Pesantren, Perhelatan Agama Dan Tradisi. Yogyakarta: LKiS, 2004. 
Munawar, Ridwan. "Ledakan Sastra Pesantren Mutakhir: Cinta, Kritisisme, Dan Industri." Suara Karya Online, Saturday, March 3 (2007). http://www.suarakarya-online.com/news. html?id=167741 (accessed 28 July 2011).

Noor, Noraini M. 'The Relationship between Wives' Estimates of Time Spent Doing Housework, Support and Wives' Wellbeing," Journal of Community \& Applied Social Psychology, Vol. 7 (1997): 413-423.

Peacock, James. "Introduction." In Javanese Lives Women and Men in Modern Indonesian Society. New Brunswick and London: Rutgers University Press, 1991.

Peha, Steve. "Welcome to Writer's Workshop," Teaching That Makes Sense, Inc., 1995. www.ttms.org (accessed 25 July 2011).

Rahman, Jamal D. "Sastra, Pesantren, Dan Radikalisme Islam." (2008). http://jamaldrahman.wordpress.com/2008/10/25/sastrapesantren-dan-radikalisme-islam/ (accessed 28 July 2011).

Renshaw, Peter. "Self-Esteem Research and Equity Programs for Girls: A Reassessment." In Hearts and Minds: Self-Esteem and the Schooling of Girls, edited by Jane Kenway and Sue Willis, 17-33. Bristol PA: The Falmer Press, 1990.

Roberts, Rosemary and Helen Creese. "Gender, Text, Performance and Agency in Asian Cultural Contexts." Intersections: Gender and Sexuality in Asia and the Pacific no. Issue 16, March (2008).

Schwalbe, M.L., V. Gecas, and R. Baxter. "The Effects of Occupational Conditions and Individual Characteristics on the Importance of Self-Esteem Sources in the Workplace." Basic and Applied Social Psychology 7 (1986): 63-84.

Sen, Krishna and David T. Hill. Media, Culture and Politics in Indonesia. New York: Oxford University Press, 2000.

Sobariah, Siti. Interview, 18 July 2011.

Srimulyani, Eka. "Negotiating Public Space: Three Nyai Generations in a Jombang Pesantren." In Indonesian Islam in a New Era: How Women Negotiate Their Muslim Identities, ed. Susan Blackburn, Bianca J. Smith, and Siti Syamsiyatun, 119-37. Victoria: Monash University Press, 2008. 
Streit, Ursula and Yolande Tanguae. "Professional Achievement, Personalty Characteristics and Professional Women's SelfEsteem." In Women Girls and Acbievement, edited by Joanne. Gullivan, Sharon Diane Crozier and Vivian M. Lalande. Ontario: Captus University Publications, 1994.

Syakur, Djunaidi A. Buku Panduan Pondok Pesantren Putri Al-Munawwir Krapyak Yogyakarta Madrasab Salafiyah Iii. Yogyakarta: Pengurus Madrasah Salafiyah, 2010/2011.

Tsolidis, Georgina. "Ethnic Minority Girls and Self-Esteem." In Hearts and Minds: Self-Esteem and the Schooling of Girls, ed. Jane Kenway and Sue Willis, 53-9. Bristol, PA: Falmer Press, 1990.

Ummah, Situs Resmi Pondok Pesantren Nurul. "Peraturan Dasar Pondok Pesantren Nurul Ummah Putri Kotagede Yogyakarta." http://www.nurulummah.com/blank.php?tentang=tentangppn u/ad art pi.html (accessed 25 July 2011).

Wenner, Jackie. "Culture, Gender and Self-Esteem: Teaching IndoChinese Students." In Hearts and Minds: Self-Esteem and the Schooling of Girls, ed. Jane Kenway and Sue Willis, 97-117. Bristol, PA: Falmer Press, 1990.

\section{Interviews}

Ana FM, interview, 10 July 2011.

Jazimah al-Muhyi, email, 5 July 2011.

Ma'rifatun Baroroh, interview, 11 July 2011.

Pijer Sri Laswiji, interview, 11 July 2011.

Rida Fitria, email, 8 July 2011.

Siti Sobariyah, interview, 18 July 2011.

Ully Maftuhah, interview, 10 July 2011. 